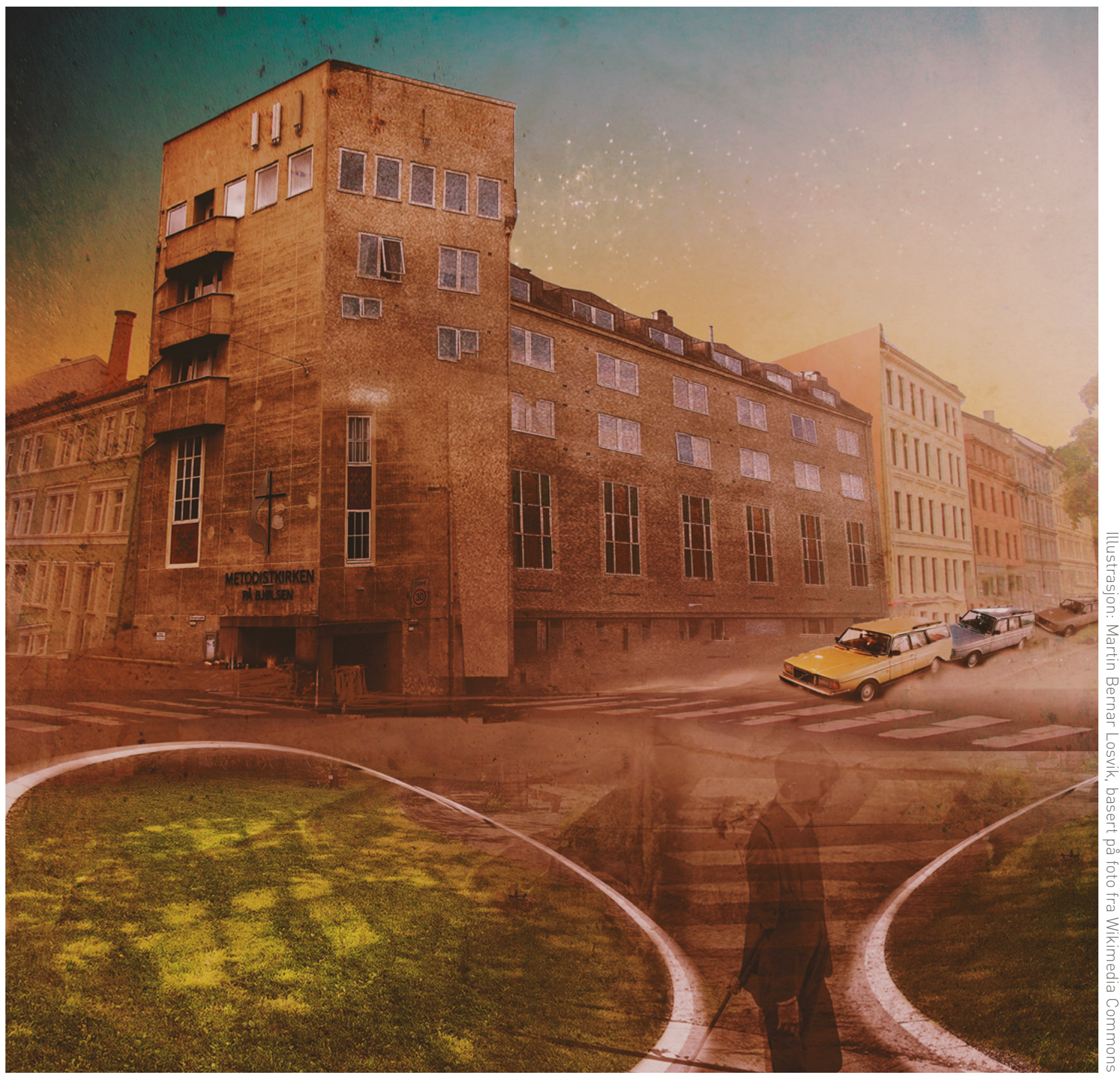

\title{
Legene i Bergensgata
} Der Bergensgata krysser Sarpsborggata på Bjølsen i Oslo finner du Metodistkirken - og i etasjene over
kirkerommet sitter Dorthe Marie Borge og Gunnar Bjaaland, fastleger og spesialister i allmennmedisin.
Bygningen der Metodistkirken holder til, er en kombinasjon av kirke og leiegård. Før dagens betongbygg kom til, sto det en liten trekirke i sveitserstil på tomten. 